\title{
Does Baccharis conferta Shrub Act as a Nurse Plant to the Abies religiosa Seedling?
}

\author{
Lázaro Rafael Sánchez-Velásquez , Diego Domínguez-Hernández, María del Rosario Pineda-López \\ and Rogelio Lara-González
}

\begin{abstract}
Instituto de Biotecnología y Ecología Aplicada, Dirección General de Investigaciones, Universidad Veracruzana, Campus para la Cultura, las Artes y el Deporte, Av. Culturas Veracruzanas No. 101, Col. Emiliano Zapata, Apartado Postal 250, 91090. Xalapa, Veracruz, México
\end{abstract}

\begin{abstract}
The role played by nurse plants represents a common ecological process in nature; this being an interaction where a particular species benefits from the presence of another species. Nurse plant species offer an efficient aid for the survival and growth of other species, including some which are of economic importance or interest for conservation. Baccharis conferta Kunth (shrub) and Abies religiosa (tree) are two common species which cohabit in the mountains of Mexico. It is general a practice, when establishing plantations to clear the mountainside, which involves cutting down and removing all shrubs. In order to discover whether $B$. conferta acts as a nurse plant when Abies religiosa seedlings are becoming established, this research evaluated the effect of this plant on the survival and growth of Abies religiosa seedlings. After taking records for two years, we found that the survival of $A$. religiosa did not vary significantly under the two contrasting conditions $(65 \%$ with $B$. conferta and $55 \%$ without $B$. conferta, nor was there significant interaction among years, contrasting conditions and experimental plots $\left(G^{2}=0.01, P>0.91\right)$. However, height and coverage were significantly greater under the $B$. conferta canopy $((t=3614, P<0.001$ and $t=2910, P<0.001$, respectively) than without $B$. conferta, but not in terms of the stem base diameter $(t=0.689, P>0.49)$. We concluded that $B$. conferta promotes the seedling growth of $A$. religiosa, reducing costs for commercial plantations or plantations aimed towards restoration.
\end{abstract}

Keywords: Mexico, nurse plant, plantation survival, seedling growth.

The knowledge of the natural processes involved in succession is fundamental to the success of species restoration and conservation programs, as well as for the maintenance of commercial forestry plantations [1-5]. Facilitation represents a successive process, where one species is capable of preparing the way for another species, and the latter can in turn prepare the way for the next one [6]. Specifically, the positive influence of an adult individual on a seedling is termed "nurse plant syndrome" and this effect is more common in environments where abiotic factors or herbivores may limit plant development $[7,8]$. The role of the nurse plant is a well documented process found in different environments and among different plant types [913]. The nurse plant can play an important role in the restoration of damaged environments and the reintroduction of locally extinct or economically important species $[1,2,4$, $8]$.

In Mexico, there are eleven recognized species from the Abies species [14], which grow in mountainous and cold areas throughout the entire length and breadth of the country, at altitudes ranging between 2000 and $3500 \mathrm{~m}$. Abies forests in Mexico occupy an area covering approximately 32000 ha

Address correspondence to this author at the Instituto de Biotecnología y Ecología Aplicada, Dirección General de Investigaciones, Universidad Veracruzana, Campus para la Cultura, las Artes y el Deporte, Av. Culturas Veracruzanas No. 101, Col. Emiliano Zapata, Apartado Postal 250, 91090. Xalapa, Veracruz, México; Tel/Fax: + 2288422773;

E-mail: lasanchez@uv.mx
[15]. In Veracruz State (Mexico) the Abies religiosa populations have declined dramatically due to uncontrolled forestry exploitation, habitat damage and land use change $[16,17]$. In this region, the fir occupies the second largest surface area, consisting of 1528 ha and is second only to pasture. In order to mitigate the effect of deforestation, the solution has principally constituted the establishing of plantations, where the usual method is to fell and erase weeds and shrubs in order to clean the planting area (pers. obs.), without considering any potential nurse species which may be naturally present [8].

Natural regeneration of fir forests is significantly greater in clearings than under the canopy [18]. According to Gonzalez et al. (1991), A. religiosa also grows in open spaces. However, it has been observed that in these open areas regeneration is more successful under the canopy of the Baccharis conferta Kunth shrub. This suggests that $B$. conferta functions as a nurse plant which facilitates the regeneration of some species of the Abies genus [19]. The questions which we asked in this study were: Does $B$. conferta act as a nurse plant for Abies religiosa? and specifically, Is the growth and survival of A. religiosa seedlings under the canopy provided by individuals from $B$. conferta than in open areas?

This research was carried out in the Cofre de Perote National Park, Veracruz, Mexico (19 $9^{\circ} 31^{\prime} 54.5^{\prime \prime}$ North and $97^{\circ} 09^{\prime} 14.8^{\prime \prime}$ West), at an approximate altitude of $3300 \mathrm{~m}$. The climate is cool, temperate and sub-humid, with an 
annual mean temperature of $12^{\circ}$ with a minimum of $-5{ }^{\circ} \mathrm{C}$ and a maximum of $22{ }^{\circ} \mathrm{C}$, with a summer rainy season and an average annual rainfall ranging between 1200 and 1500 $\mathrm{mm}$. Abies religiosa is used for Christmas trees and mature trees provide wood for housing, furniture, construction, roofing, firewood and fencing.

The A. religiosa distribution is from Guatemala to Mexico, it is a lush tree in appearance, as some of their extensive branches grow only a short distance from the ground. They grow to a height of 35 to $40 \mathrm{~m}$ with trunk diameters normally exceeding $1.5 \mathrm{~m}$. Twigs grow in a cross formation with alternate leaves which are linear and pointed, $20 \mathrm{~mm}$ long and bright green on top and dull on the underside and they have a sharp apex which is sometimes rounded. It is a monoecious plant. Age for reproduction ranges begin between 23 and 27 years. This species is considered to be shade tolerant, however it regenerates well in gaps between the canopy [18] Baccharis conferta Kunth (Asteraceae) is a shrub which grows to between 1 and $3 \mathrm{~m}$ high, with multiple stems, is endemic to Mexico and is known by the name of "quauhizquiztli" and is used to make rustic brooms (for street sweeping); it has spasmolytic and antibacteria properties as well as containing compounds such as flavonoids and triterpenes $[20,21]$. B. conferta does not grow under the $A$. religiosa canopy but develops in open areas and is considered a pioneer species. Both $B$. conferta and $A$. religiosa share certain species of ectomycorrhizal fungi and it is thought that $B$. conferta serves as a backup source of ectomycorrhizal fungi for A. religiosa (Andrade Torres et al. pers. com.).

Experimental Design. Two open areas with Baccharis conferta plants ( $70-80 \%$ coverage) were random chosen. In each area a $16 \times 48 \mathrm{~m}$ area was traced out. Each area was subdivided into eight plots measuring $10 \times 8 \mathrm{~m}$ and four rectangles were randomly chosen where the $B$. conferta was left intact and four where $B$. conferta was absent; here the elimination of all $B$. conferta plants with a machete resulted in the plots being totally devoid of ground cover. In order to avoid a border effect, a meter wide perimeter was left along each side of the rectangle. In the first plot 114 A. religiosa were planted with a distribution of 14 seedlings per rectangle, 56 in the four rectangles where there was no $B$. conferta and 57 in the four rectangles where $B$. conferta was present. In the second plot $120 \mathrm{~A}$. religiosa seedlings were planted, 60 seedlings in the four rectangles without any $B$. conferta and 60 in the four rectangles where $B$. conferta was present. Fifteen seedlings were planted in each rectangle. Planting of seedlings was equidistant (distance between plants was $2 \mathrm{~m}$ ). A. religiosa seedlings used in this project were taken randomly selected areas from naturally regenerating forest, where they are very abundant. Seedlings were removed with the entire root ball, so as not to damage the root, with heights ranging between 20 and $35 \mathrm{~cm}$ and aged approximately two year (whorls in Abies are produced at the rate of one whorl per year -[22, 23]. After a month, dead seedlings were removed and replaced with living plants (obtaining $100 \%$ survival rate). Immediately after planting, the height, coverage and trunk base diameter of each seedling was recorded and these measurements were taken every year over a two year period. In order to measure the height and coverage we employed a flexible measuring tape and for the diameter, a metal outside caliper.
Methods of analysis. In order to compare survival (number of individuals at the end of the study) under the two contrasting conditions (nurse-no nurse), years (1 and 2), plots (1 and 2) (principal effects) and the interaction among contrasting conditions, year and plot, a log- linear models [24] were employed. The growth height, coverage and trunk base diameter were analyzed by applying the student's $t$ test [24]. Growth rates were estimated by applying the following equation:

$\Delta_{C}=\frac{\ln C_{2}-\ln C_{1}}{t}$

where $\Delta_{C}$ is the growth rate, $\ln$ is the natural logarithm, $C_{2}$ is the final height (coverage or trunk base diameter), $C_{1}$ is the initial height (coverage or trunk base diameter) and $t$ is time taken.

\section{RESULTS}

The survival rate of $A$. religiosa seedlings under the canopy of $B$. conferta canopy was $65 \%$, whereas the survival rate in the gaps was $55 \%$ (Fig. 1). However, there were no significant differences between contrasting conditions, years, or plots $\left(G^{2}=0.46, d f=4, P=0.9775\right)$ or when their interactions are included $\left(G^{2}=0.01, d f=1, P=0.9124\right)$..

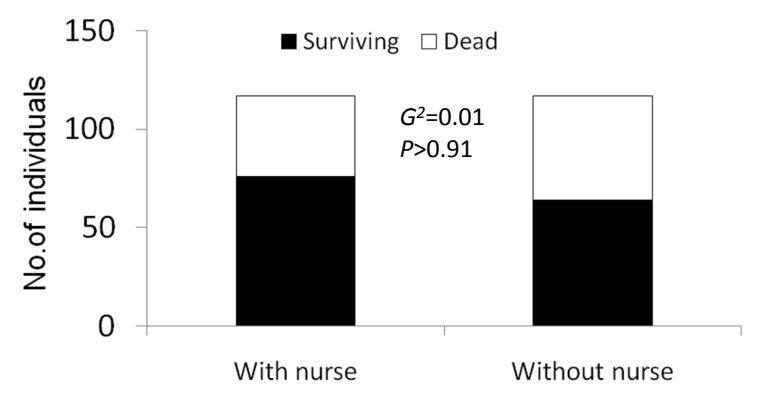

Fig. (1). Number of live and dead seedlings of Abies religiosa after two years planted. Nurse Baccharis conferta.

Out of the three variables recorded (height, coverage and diameter at the base) we found that growth rates, in terms of height and cover were significantly greater for the seedlings of A. religiosa that grew under the cover of $B$. conferta than without cover $\left(17.2 \pm 1.9 \mathrm{~cm}, 33472 \pm 764 \mathrm{~cm}^{2}\right.$ and $9.88 \pm 0.93$ $\mathrm{cm}, 2234 \pm 152 \mathrm{~cm}^{2}$, respectively) ( $t=3614, P<0.001$ and $t$ $=2910, P<0.001$, respectively). Whereas the expansion in trunk diameter manifested no significant differences in terms of the contrasting conditions $\left(1.88 \pm 0.63\right.$ and $1.6 \pm 0.34 \mathrm{~cm}^{2}$, respectively) ( $t=0.689, P>0.492)$ (Fig. 2).

\section{DISCUSSION}

Some research has indicated that the regeneration of $A$. religiosa thrives under the closed canopy $[15,17,25]$, whereas Lara- Gonzalez et al. (2009) demonstrated that regeneration of $A$. religiosa is significantly higher in canopy gaps than it is under the canopy. However, in open areas it has been suggested that regeneration of $A$. religiosa occurs in association with $B$. conferta [19]. Our results to some extent support this hypothesis, because the survival of seedlings of A. religiosa was not significantly different when individuals were growing under $B$. conferta, compared to those in open 
spaces. However, it was observed that the height and seedling coverage of $A$. religiosa increased significantly when they grew below the canopy provided by $B$. conferta individuals, when compared to open areas. On other Mexican forest $B$. vacciniodes, a species which is functionally similar to $B$. conferta acts as a nurse species to Quercus spp. and Pinus spp. in the highlands of Chiapas in Mexico [26]. In the case of other species found in temperate forests (e.g. Quercus rugosa, Q. castanea, Magnolia dealbata, M. iltisiana) it has been shown that the survival of their seedlings is significantly greater under a nurse species than in open areas [4, 27-30]. This seems to indicate that both in temperate zones, as well as in many types of ecosystems [8], nurse plants are more common than previously thought.

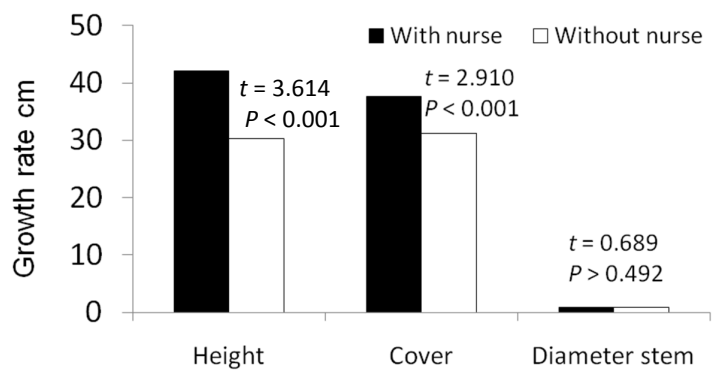

Fig. (2). Annual growth rate by height, coverage and trunk diameter of Abies religiosa seedlings after two year planted (plot average). Nurse Baccharis conferta.

Nurse plants include shrubs, broad-leaved trees, pines, grasses and agaves, among others. Shrubs have proved to be the most successful type of nurse plants [29]. The role of the nurse may be to provide shade during the summer dry season which reduces the stress on seedlings caused by drought [33]. Most pioneer species such as B. conferta are important as they are able to act as facilitators; offering protection from weeds, wind action, frost and generally against sudden temperature changes [32]. Pines for example promote the survival and growth of many broad leaf species $[5,36]$. We know that without the presence of these nurse plants, very high seedling mortality can occur $[4,34,35]$.

If certain species of shrubs act as nurse plants, then this process can be used to aid in restoration and rehabilitation projects for these ecosystems, protecting seedlings from drought, trampling by ungulates and impact from abrupt changes in climate $[8,31,36-38]$. A reduction in vegetation cover also reduces the soil's ability to retain water and increases evaporation rate [39], facilitating the invasion of annual species with lower water requirements [40] and accelerating the decline of native annual species, associated with trees and shrubs.

Also Abies is a genus which reproduces with relative ease in natural forests, even though it tends to register low percentages of viability and a high number of empty seeds [41]. Likewise, A. religiosa is a species which grows extremely slowly when in the nursery [42]. Thus, the extraction of seedlings from natural forests with high densities of regeneration may offer an option for procuring seedlings for the restoration of degraded areas. Alternatively, in other reforestation programs in Mexico, it is common practice to clear the area to be reforested, or in other words to cut down shrubs and perennial and annual grasses (pers. obs.). This practice incurs costs and in the case of species which require a certain amount of shade in order to become established and grow vigorously, this eliminates the possibility of maintaining a favorable environment, where the plantation can be more successful. This is the case of plantations of $A$. religiosa; a species with a certain capacity for shade tolerance, and thus we recommend that reforestation programs of this kind should not eliminate $B$. conferta ground cover, at least during the first two years subsequent to planting.

In short, we can conclude that in the case of $A$. religiosa plantations, it is not necessary to remove the $B$. conferta shrubs, as neither the establishment, nor the survival of $A$. religiosa seedlings depends on the presence or absence of this shrub. On the other hand, both the height and coverage of $A$. religiosa seedlings was greater under the $B$. conferta canopy, which can also provide protection against cattle should they escape from grazing areas.

\section{ACKNOWLEDGEMENTS}

This work was subsidized by the CONAFOR CONACYT departmental funds, code number: 2002-C016163, and the PRODUCE - Ver (PRODUVER ) Foundation. Besides this, part of the research was carried out by the Department for the Generation and Application of Knowledge in the area of Plant Ecology and Restoration renewal for the Ecology and Conservation of Forest Biodiversity, subsidized by funds from the Faculty Improvement Program ( PROMEP ) promoted by the Secretary for Education. We thank Claudia Alvarez Aquino for her suggestions referring to the first rough draft of the manuscript.

\section{REFERENCES}

[1] Ashton PM, Gamage S, Gunatilleke IAUN, Gunatilleke CVS. Restoration of a Srilankan rainforest: Using Caribbean pine Pinus caribea as a nurse for establishing late succession tree species. J Appl Ecol 1997; 34: 915-25.

[2] D'Antonio CL, Meyerson A. Exotic plant species as Problems and solutions in ecological restoration: a synthesis. Restoration Ecol 2002; 10: 703-13.

[3] Walker LR, del Moral R. Primary succession and ecosystem rehabilitation. UK: Cambridge University Press 2003.

[4] Ramírez-Bamonde ES, Sánchez-Velásquez LR, Andrade-Torres A. Seedling survival and growth of three species of mountain cloud forest in Mexico, under different canopy treatments. New Forests 2005; 30: 95-101.

[5] Sánchez-Velásquez L, Pineda-López MR, Galindo-González J, Díaz-Fleischer F, González JLZ. Opportunity for the study of critical successional processes for the restoration and conservation of mountain forest: the case of mexican pine plantations. Interciencia 2009; 34: 519-21.

[6] Connell JH, Slatyer RO. Mechanisms of succession in natural communities and their role in community stability and organization. Am Naturalist 1977; 111: 1119-44.

[7] Niering WA Whittaker RH, Lowe $\mathrm{CH}$. The saguaro: a population in relation to its environment. Science 1963; 142:15-23.

[8] Padilla FM, Pugnaire FI. The role of nurse plants in the restoration of degraded environments. Front Ecol Environ 2006; 4: 196-202.

[9] Valiente-Banuet A, Ezcurra E. Shade as a cause of the association between the cactus Neobuxbaumia tetetzo and the nurse plant Mimosa luisana in the Tehuacan valley, México. J App Ecol 1991; 79: 961-97. 
[10] Pugnaire FI, Haase P, Puigdefabregas J. Facilitation between higher plant species in a semiarid environment. Ecology 1996; 77 : 1420-6.

[11] Callaway RM, Pugnaire FI. Facilitation in plant communities. In: Pugnaire FI, Valladares F Eds. Handbook of functional plant ecology. USA: Marcel Deckker, Inc 1999; pp. 623-48.

[12] Tewksbury JJ, Lloyd JD. Positive interactions under nurse-plants: spatial scale, stress gradients and benefactor size. Berlin, ALLEMAGNE: Springer; 2001; Vol. 127.

[13] Sánchez-Velásquez LR, Quintero-Gradilla S, Aragón-Cruz F, Pineda-López MR. Nurses for Brosimum alicastrum reintroduction in secondary tropical dry forest. For Ecol Manag 2004: 401-4.

[14] Aguirre-Planter E, Furnier GR, Eguiarte LE. Low levels of genetic variation within and high levels of genetic differentiation among populations of species of Abies from southern Mexico and Guatemala. Am J Bot 2000; 87: 362-71.

[15] Rzedowsky J. La vegetación de México. México: Limusa 1978.

[16] Jardel E. Efecto de la explotación forestal en la estructura y regeneración del bosque de coníferas de la vertiente oriental del Cofre de Perote, Ver., México. Biótica 1986; 11: 247- 69.

[17] Sánchez-Velásquez LR, Pineda-López MR, Hernández A. Distribución y estructura de la población de Abies religiosa (H.B.K) Sch1. et Cham. En el Cofre de Perote, Edo. de Veracruz, México. Acta Bot Mex 1991; 16: 45-55.

[18] Lara-González R, Sánchez-Velásquez LR, Corral-Aguirre J. Regeneration of Abies religiosa in canopy gaps versus understory, Cofre de Perote National Park, México. Agrociencia 2009; 43: 7394.

[19] Snook L. Conservation of the monarch butterfly reserves in México: Focus on the forest. In: Malcolm S, Zalucki M, Eds. Biology and Conservation of the Monarch Butterfly. Natural History Museum of Los Angeles Country: Los Angeles 1993; pp 362-75.

[20] Weimann C, Göransson U, Pongprayoon-Claeson U, Claeson P, Bohlin L, Rimpler H, Heinrich M. Spasmolytic effects of Baccharis conferta and some of its constituents. J Pharm Pharmacol 2002; 54: 99-104.

[21] Freire SE, Urtubey E, Giuliano DA. Epidermal characters of Baccharis (Asteraceae) species used in traditional medicine. Caldasia 2007; 29: 23-38.

[22] Silvertown J, Dodd M. Evolution of life history in balsam fir (Abies balsamea) in subalpine forests. Proc R Soc Lond Series B: Biological Sciences 1999; 266(1420): 729-33.

[23] Rasmussen H, Soerensen S, Andersen L. Bud set in Abies nordmanniana Spach. influenced by bud and branch manipulations. Trees - Struct Funct 2003; 17: 510-14.

[24] SAS, SAS-STAT User's Guide: release 6.03 edition, ed. CSII Staff: SAS Institute Inc. 1988.

[25] Figueroa BL, Moreno S. Estructura y sucesión en poblaciones de Abies religiosa y Abies religiosa var. emarginata de la Sierra de Manantlán, Jalisco. Agrociencia 1993; 3: 49-63.

[26] Ramírez-Marcial N, González-Espinosa M. García-Moya E. Establecimiento de Pinus spp y Quercus spp. en matorrales y pastizales de Los Altos de Chiapas. Agrociencia 1996; 30: 249-57.
[27] Bonfil SC, Rodríguez H, Peña RV. Evaluación del efecto de las plantas nodrizas en el establecimiento de una plantación de Quercus L. Ciencia Forestal 2000; 88: 59-73.

[28] Castro J, Zamora R, Hóldar JA, Gómez MG, Gómez-Aparicio L. Benefits of using shrubs as nurse plants for reforestation in Mediterranean mountains: A 4-Year Study. Restoration Ecol 2004; 12: $352-58$

[29] Gómez-Aparicio L, Zamora R, Gómez JM, Hóldar JA, Castro J, Baraza E. Applying plant facilitation to forest restoration: a metadata analysis of the use of shrubs as nurse plants. Ecolo Appl 2004; 14: 1128-38.

[30] Zamora R, Sal AG, Soriger R, Fernández-Haeger J, Jordano D, Jordano P. Herbivoría en espacios protegidos. Ecosistemas 1996; 18: $70-1$.

[31] Marañon T, Zamora R, Villar R, Zavala MA, Quero JL, PerezRamos I, MendozaI, Castro J. Regeneration of tree species and restoration under contrasted Mediterranean habitats: field and glasshouse experiments. International J Ecol Environ Sci 2004; 30: 187-96.

[32] Suzán H, Nabhan GP, Patten DT. The importance of Olneya tesota as a nurse plant in the Sonoran Desert. J Veg Sci 1996; 7: 635-44.

[33] Gómez-Aparicio L, Zavala MA, Bonet FJ, Zamora R. Are pine plantations valid tools for restoring Mediterranean forests? An assessment along abiotic and biotic gradients. Ecol Appl 2009; 19: 2124-411.

[34] Barchuk AH, Díaz MP. Vigor de crecimiento y supervivencia de plantaciones de Aspidosperma quebracho-blanco y de Prosopis chilensis en el Chaco árido. Quebracho 2000; 8: 17-29.

[35] Castro J, Zamora R, Hóldar JA, Gómez J. Use of shrubs as nurse plants: A new technique for reforestation in mediterranean mountains. Restoration Ecol 2002; 10: 297-305.

[36] Castro J, Gómez JM, García D, Zamora R, Hóldar JA. Seed predation and dispersal in relict Scots pine forests in southern Spain. Plant Ecol 1999; 145: 115-23.

[37] Gómez JM, Hódar JA, Zamora R, Castro J, García D. Ungulate damage on Scots pines in Mediterranean environments: effects of association with shrubs. Can J Bot 2001; 79: 739-46.

[38] Castro J, Zamora R, Hóldar JA, Gómez JM. Use of shrubs as nurse plants: A new technique for reforestation in Mediterranean mountains. Restoration Ecol 2002; 10: 297-305

[39] Keeley SC, Johnson AW. A comparison of the pattern of herb and shrub growth in comparable sites in Chile and California. Am Midland Nat 1977; 97: 120-32.

[40] Vidiella PE, Armesto JJ. Emergence of ephemeral plant species from soil samples of the Chilean coastal desert in response to experimental irrigation. Rev Chilena Hist Nat 1989: 99-107.

[41] Nieto-Pascual C, Musálem MA, Alcalá JO. Estudio de algunas características de conos y semillas de Abies religiosa (HBK) Schl et Cham. Agrociencia 2003; 37: 521-31.

[42] Moreno-Chavez LR, López MAL, Estañol-Botello E, VelásquezMartínez A. Diagnóstico de necesidades de fertilización de Abies religiosa (H.B.K) Schl. et Cham. en vivero mediante DRIS. Madera Bosques 2002; 8: 51-60. 